\title{
MANUFACTURING OF CURD PRODUCTS OF INCREASED BIOLOGICAL VALUE FOR THE ELDERLY FROM DRIED COMPONENTS
}

\author{
Ludmila A. Zabodalova, Maria S. Belozerova $\stackrel{\varpi}{ }$, Tatiana N. Evstigneeva \\ Department of Applied Biotechnology, ITMO University \\ Lomonosova 9, 191002, Saint Petersburg, Russia
}

\begin{abstract}
Background. In recent years, the number of elderly people has increased, and the diseases that arise in old age are associated, amongst other factors, with malnutrition. In the elderly, the need for primary nutrients and energy changes, so the development of food products intended for this particular group of people is becoming increasingly important. The purpose of this research is to work out the composition of and technology for producing low-fat curd products from raw milk and vegetable components. The developed products can be used for their gerodietetic properties, because nutritional and energy needs in the elderly were taken into account when designing the product. The curd product was manufactured from skimmed dried milk (SDM), soy isolate protein (SIP) and spelt grain.

Material and methods. Optimal conditions for the recombination of SIP were determined. The influence of mass fraction of SIP on the properties of the clot and the end product was studied. The degree of dispersion of the grain component was determined, from the organoleptic evaluation of samples of the mixture, and the optimum method of addition was chosen. The method of adding cooked spelt into the clot after pressing was chosen. Harrington's generalized desirability function was used for the calculation of the optimum mass fraction of the grain component in the end product.

Results. The formulation and technology for a curd product based on dry ingredients were determined. The amino acid composition and content of essential components in the developed product were determined, and the biological and nutritional value were calculated.

Conclusions. The use of dry ingredients for the production of a curd product makes it possible to manufacture the product in the absence of raw milk. The formulation of the product is designed taking into account the needs of the body in old age. The incorporation of spelt increases the biological value of the curd product to $81.5 \%$.
\end{abstract}

Keywords: curd product, skimmed dried milk, soy protein, spelt

\section{INTRODUCTION}

The health of every person and nation is defined mainly by the typical diet (Tihomirova, 2001). Epidemiological and clinical research shows that such factors as diet and lifestyle are among the most important causes of increasing rates of cancer, diabetes, obesity and other ailments (Hezeker, 2000). Within the next twenty years, the number of people over 60 will exceed one billion (Cichero, 2016). Increasing numbers of elderly

This work was partially financially supported by the government of the Russian Federation, Grant 074-U01.

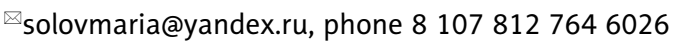


people in the demographic structure of Russia makes it necessary to study the elderly population and their nutritional requirements (Andreenko et al., 2007).

The requirements of basic nutrients and energy changes as a person ages. The ratio of proteins, fats, and carbohydrates in the diet of an elderly individual should be $1.0: 0.8: 3.5$. Nutrition in Russia is characterized by a serious disfunction. This is a deficiency of animal protein, especially amongst low-income individuals (Tutelian and Kniazev, 2000). Producing additional animal and vegetable proteins cannot solve this problem, but one quick and efficient solution could be provided by processed soybean products and similar plant-based proteins (Prianischnikov et al., 1999).

Soy proteins are one of the most valuable plant proteins, because their amino acid composition is similar to animal proteins. Soy proteins have a higher digestibility compared to other proteins of vegetable origin. National policy regarding healthy nutrition has paid particular attention to biotechnological recycling of agricultural raw materials, particularly the development of production technologies for new products with changed chemical compositions. Therefore, the development of a range of products and diets balanced on amino acids, fatty acids, vitamins and minerals can be kept up-to-date (Kozlov, 2004).

Functional food products based on milk have received significant interest in recent years. Cereal-based components, including dietary fiber (wheat bran), vitamins and cereal additives, are used to enrich dairy products by increasing their protein content (Shetinin and Mysina, 2002).

In this study, spelt, a high-protein variety of wheat, was chosen as the grain component. It was used to increase the biological value of the curds, since milk and soy proteins have identical limiting amino acids.

The results of research that was carried out in Belgium showed that spelt contains more lipids and unsaturated fatty acids than soft wheat. Spelt is characterized by high ash content, and high levels of copper, iron, zinc, magnesium, and phosphorus (Ruibal-Mendieta et al., 2005).

Comparative research into the composition of spelt and bread-making wheat was carried out in Turkey. These tests showed that spelt contains more flavonoids and has higher antioxidant activity (Serpen et al., 2008).
Using spelt allows a product with a higher content of carbohydrates to be obtained. A deficiency of this in the diet can lead to problems with protein metabolism. The addition of spelt increases the content of tyrosine. Tyrosine, with a limited proportion of protein, contributes to longer life. The amount of sulfur-containing amino acids increases. These, together with glutamic acid, are geroprotector nutrients with antioxidant properties (Petrov et al., 2001).

Fermented milk products play an important role in the human diet and maintaining the immune system (Akatsu et al., 2016). This applies to curds and curd products, which have ahigh content of calcium and phosphorus, salts, protein and milk fat (Tihomirova, 2001).

Manufacturing curds is a time-consuming process. This process requires a considerable amount of milk. Dairy producers are currently experiencing a shortage of raw materials, especially in the winter.

One way to solve this problem is to use dried milk components in the manufacture of cottage cheese. This technological method provides the regional population with valuable products, without natural milk (Kuznecov and Schiller, 2006).

Curd products manufactured from dry components, such as milk powder, raw materials of vegetable origin, such as soybean isolates, and cereals will provide a product which is balanced in its amino acid composition, and will require less raw milk. The good compatibility of curds with flavoring will allow an assortment of curd products for a wide range of consumers to be created.

\section{MATERIAL AND METHODS}

\section{Materials}

1. SIP (Pro-Vo DR) was provided by "Protein. Technology. Ingredients" (Russia) with a protein mass fraction of $90 \%$.

2. SDM (Production Unitary Enterprise "Kalinkovichi Dairy Plant", Republic of Belarus). Nutritional value SDM (content per $100 \mathrm{~g}$ of product): fat $1.5 \mathrm{~g}$; protein not less than $32.0 \mathrm{~g} ; 50.0 \mathrm{~g}$ of lactose; the energy value of 341 kilocalories.

3. Samples of the spelt (Triticum dicoccum) varieties Volzhskaya and Belka were provided by N. I. Vavilov Research Institute of Plant Industry, Saint Petersburg. The average chemical composition of 
the grain of spelt is: ash $-1.44 \%$, protein $-17.70 \%$, fat $-1.90 \%$, carbohydrate $-57.4 \%$, fiber $-12.5 \%$ (Bazenova, 2004; Yukov and Lihacheva, 2005).

4. A freeze-dried Direct Vat Set (DVS) Mesophilic Homofermentative Culture, containing Mesophilic Lactococcus (CHR HANSEN, Denmark).

\section{Measurements}

We used standard research methods to investigate the physico-chemical, organoleptic, microbiological, structural and mechanical properties of curd clot and curd products. Experimental studies were carried out in three to five repetitions. In determining the rehydration conditions of SIP, the method applied in the dairy industry to determine the solubility index of dry dairy products was used.

To measure the $\mathrm{pH}$, a $\mathrm{pH}-410 \mathrm{pH}-$ meter with combined glass electrode (Russia) was used. The determination of the moisture content of the curd products was carried out by an accelerated method, using an ELEX-7 device for determining the moisture content of the raw materials and food products (Russia).

The determination of rheological parameters was made by a Rheotest 2 (Germany). For this study, a curd product measuring device $\mathrm{H}$, designed for highviscosity materials, was used. A measuring device $\mathrm{N}$ was used for studying the clot. The samples were subjected to curd product deformation, with a velocity gradient ranging from 0.3333 to $145.8 \mathrm{~s}^{-1}$.

\section{Preparation of a mixture for the production of a curd product}

The curd product was prepared from reconstituted milk by the acid method. Z. M. Tskitishvili and N. N. Lipatov developed this technology. The recovery of components was carried out apart separately. Recovery was carried out under standard SDM modes.

We investigated the influence of $\mathrm{pH}$, heat treatment mode, the intensity of the mechanical effect, the combined influence of heat treatment (determining maximum solubility) and mechanical impact on the solubility of the SIP in order to determine the recovery mode of SIP. The optimal reconstitution parameters was the following: dissolving SIP in water at a temperature of $40^{\circ} \mathrm{C}$, heating the resultant solution to $70^{\circ} \mathrm{C}$ and stirring at this temperature for 5 minutes using a stirrer with a rotation rate of $1000 \mathrm{~min}^{-1}$.
The amount of SDM and SIP in the mixture was prepared in the ratio $75: 25 ; 50: 50 ; 25: 75$, with a mass fraction of protein in the mixture of $3.0 \%$. When we increased the mass fraction of SIP, the amount of solids decreased. To provide a mass fraction of protein in the mixture of $3 \%$, fewer components were required, because dry SIP contains no less than $90 \%$ protein.

The resulting mixture was pasteurized at a temperature of $78 \pm 2^{\circ} \mathrm{C}$, with a delay of 15 seconds. The mixture was cooled to fermentation temperature and an activated starter culture, in a quantity of $3 \%$ by weight of the mixture, was added.

The duration of fermentation was chosen based on preliminary research regarding clot quality, obtained by the production of a curd product with ratio of SDM : SIP $25: 75 \%$. This ratio was chosen due to the fact that this proportion of soybean of the mixture will allow maximum variation of its properties.

\section{Statistical evaluation of the data}

Statistical processing of the results was carried out using Microsoft Office Excel and Curve Expert, using Student's criterion.

\section{RESULTS AND DISCUSSIONS}

\section{Research regarding the fermentation process and the choice of mass fraction of soy isolate in the mixture}

The intensity of the increase in titratable acidity decreased with an increase in the proportion of SIP in a mixture. The clot became less solid with smaller flakes. Investigations of the rise in acidity during fermentation showed that, for samples with an amount of SIP of less than $50 \%, 5$ hours is sufficient to form a dense clot ready for further processing. Therefore, the duration of fermentation was increased to 8 hours for all samples, independently of the mass fraction of the ISF in the mixture. We analyzed the increase in titratable acidity, as the samples had different initial acidities (due to component ratio).

Figure 1 shows the dependence of maximum increase in titratable acidity and the time to reach the maximum level of titratable acidity relative to mass fraction of SIP in the mixture. 

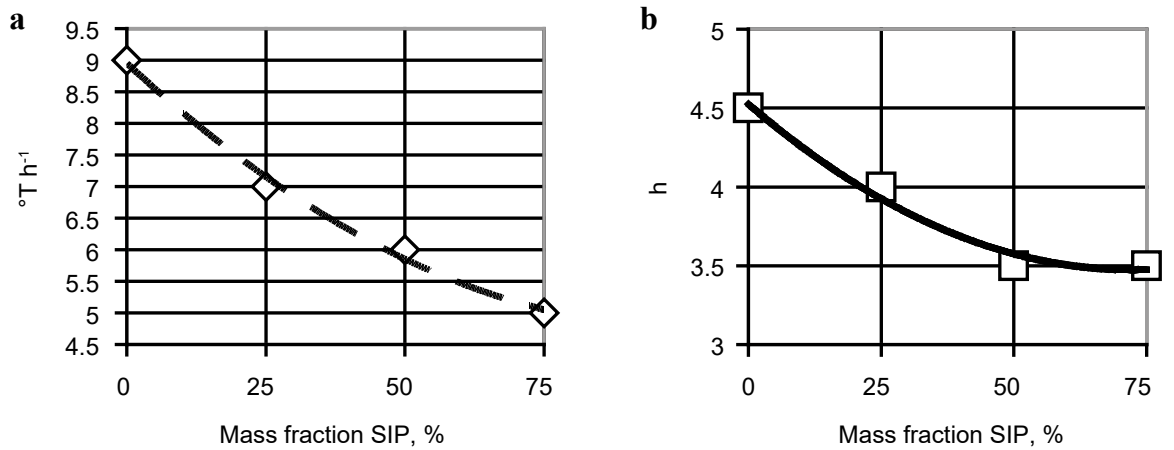

Fig. 1. Dependence of the maximum increase in acidity (a) and the time to reach maximum increase in titratable acidity (b) on mass fraction of SIP

The graph shows that the maximum increase in titratable acidity and the time to achieve this increase decreases with increasing mass fraction of SIP. Clot formation required less time. The clot was formed at a lower value of titratable acidity.

The equations which describe the relationship between the magnitude of the maximum increase in titratable acidity $\left(y_{1}\right)$, the length of time necessary to achieve it $\left(y_{2}\right)$ and the mass fraction of $\operatorname{SIP}(x)$ have the following forms:

$$
\begin{array}{ll}
y_{1}=8.95-0.08 x+0.0004 x^{2}, & S=0.22, R^{2}=0.994 \\
y_{2}=4.53-0.03 x+0.0002 x^{2}, & S=0.11, R^{2}=0.982
\end{array}
$$

The following conclusions were drawn from research into the process of clotting, and the quality of clots: duration of fermentation decreases with increasing mass fraction of SIP; the duration of fermentation was 5 hours for samples of curd products with a mass fraction of SIP of $75 \%$ and $50 \%$. This time is sufficient to form a dense clot suitable for further processing.
When fermentation time was increased, the structure of the clot became firmer and it became compressed. Spontaneous pressing off of whey occurs at the stage of fermentation of the mixture.

The increase in the proportion of the soybean component in the mixture reduced the water retention ability of the clot. Soy globulins may have better syneresis properties compared to cow's milk proteins.

Self-pressing was carried out for $50 \mathrm{~min}$. The water retention ability of the clots decreased with increasing mass fraction of SIP. The basic amount of whey was expelled during first 25-30 minutes of self-pressing.

The processing of the clot showed that cooking reduced the loss of solids from whey. Table 1 shows the physical and chemical properties of curd product and whey.

The product had a homogeneous, pasty consistency and fermented taste, with soy isolate causing variations in flavor intensity. Color was from white to cream, depending on the mass fraction of SIP in the mixture.

Table 1. Physico-chemical properties of curd product and whey

\begin{tabular}{lcccc}
\hline \multirow{2}{*}{ Properties } & \multicolumn{3}{c}{ Ratio SDM : SIP, \% } \\
\cline { 2 - 4 } & control sample & $75: 25$ & $50: 50$ & $25: 75$ \\
\hline Moisture content, $\%$ & $79.5 \pm 0.4$ & $80.5 \pm 0.5$ & $80.4 \pm 0.5$ & $80.6 \pm 0.5$ \\
Titratable acidity, ${ }^{\circ} \mathrm{T}$ & $190.0 \pm 5.0$ & $176.0 \pm 5.0$ & $138.0 \pm 4.0$ & $108.0 \pm 4.0$ \\
Mass fraction of solids in whey, $\%$ & $5.9 \pm 0.4$ & $4.5 \pm 0.3$ & $2.9 \pm 0.3$ & $2.0 \pm 0.3$ \\
Titratable acidity of whey, ${ }^{\circ} \mathrm{T}$ & $55.0 \pm 3.0$ & $46.0 \pm 2.0$ & $25.0 \pm 2.0$ & $18.0 \pm 2.0$ \\
\hline
\end{tabular}




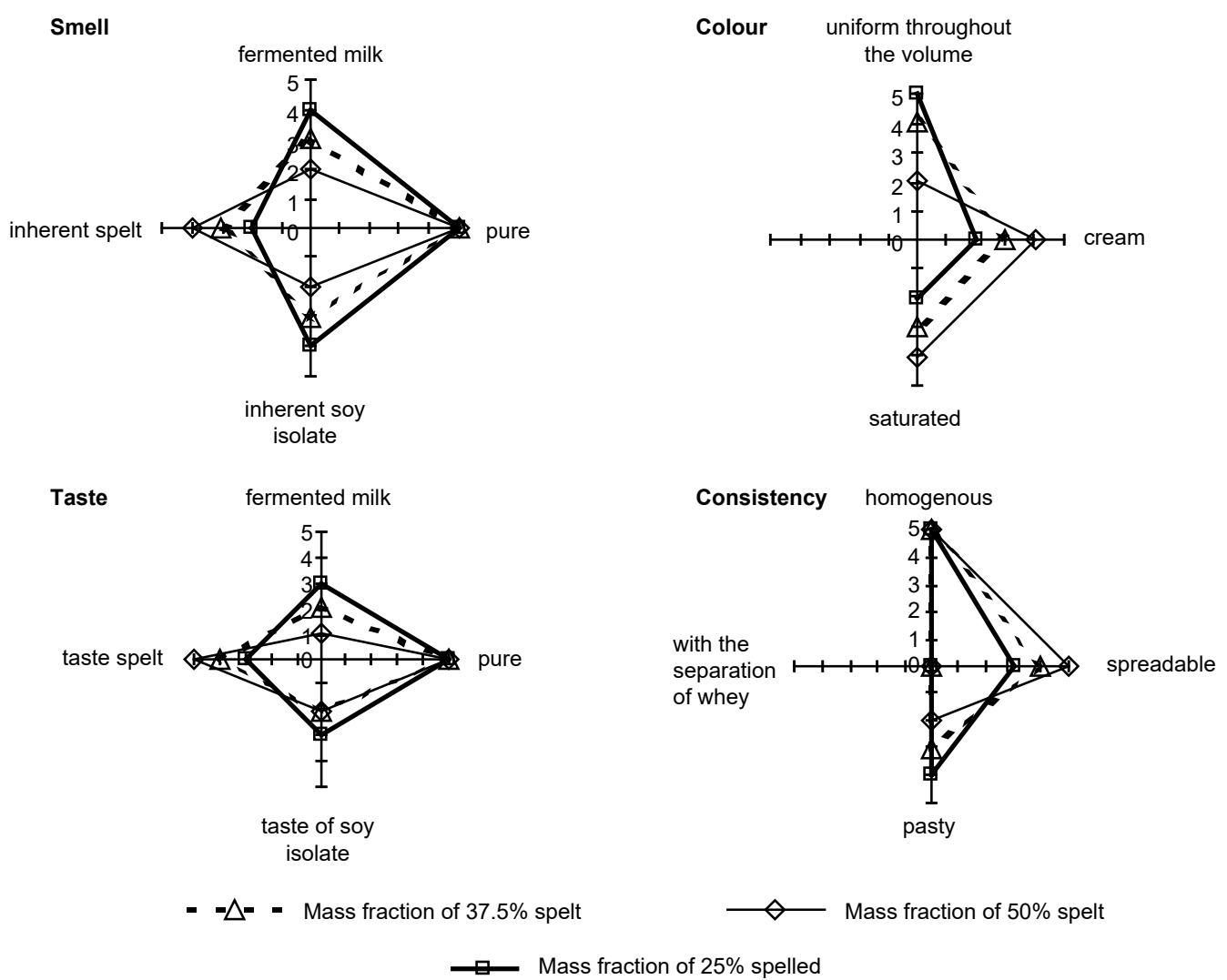

Fig. 2. Spider plots of sensory attributes (lowest $=0$; highest $=5$ ) of curd product samples with spelt

Organoleptic properties of the curd product are shown in Figure 2. The consistency of the clot became less dense with increasing mass fraction of SIP. The soy flavor became more pronounced, particularly when SIP was added in a proportion greater than $50 \%$ by weight of the mixture. The ratio of SDM to SIP was equal to $50: 50$, which was recognized as optimal. This ratio allows the product to have equal content of animal and vegetable proteins.

\section{Selecting an optimal mass fraction of the grain component in the mixture}

Spelt was chopped to a particle diameter of $0.5 \mathrm{~mm}$. This degree of dispersion was selected by sensory evaluation of mixture samples with different sizes of grain component. The grain component was added to the mixture with a ratio of SDM : SIP of $50: 50 \%$.

Boiled spelt was added to the clot after compression. If grain is added before pasteurization, even in small amounts ( $1-2 \%)$, the spelt settles during fermentation, and the clot has a lower density. The intensity of whey separation reduced in comparison to the separation of whey of clot produced from SDM and SIP without spelt. Harrington's generalized desirability function was used in order to determine the optimal composition of the product. The following factors were selected to characterize the developed product: coefficient of amino acid conformity $\left(y_{1}\right)$, factor of comparable redundancy $\left(y_{2}\right)$, mass fraction of spelt $\left(y_{3}\right)$, which influenced the composition of the developed product and its biological value $\left(y_{4}\right)$. Mass fraction of spelt was set in the range of $10-50 \%$ at $2.5 \%$ intervals. Individual desirability functions were obtained for each of these parameters. From individual functions, the generalized desirability function $D$ was derived:

$$
\begin{gathered}
D=\exp \left\{-1 / 4\left[\exp \left(-0.89+2.06 y_{1}\right)+\exp (2.0-\right.\right. \\
\left.\left.\left.4.95 y_{2}\right)+\exp \left(1.9-0.04 y_{3}\right)+\exp \left(-2.5+0.05 y_{4}\right)\right]\right\}
\end{gathered}
$$


Zabodalova, L. A., Belozerova, M. S., Evstigneeva, T. N. (2018). Manufacturing of curd products of increased biological value for the elderly from dried components. Acta Sci. Pol. Technol. Aliment., 17(2), 177-184. http://dx.doi.org/10.17306/J.AFS.2018.0545

The highest value of $D$ is equal to 0.601 , which was obtained for the sample with a mass fraction of spelt of $37.5 \%$. Based on this, it can be assumed that this sample was the most preferred, since a further increase in the mass fraction of the grain component in the mixture reduced the desirability function.

\section{Study of the quality of the end product}

The cereal component was added in a proportion of dry spelt of $25 \%, 37.5 \%$ and $50 \%$ by weight of the clot after pressing, in order to confirm calculation data about the mass fraction of grain components, taking into account the organoleptic, physical, chemical, structural and mechanical properties of the product.

Because cooked spelt was added into the product, an increase in the mass fraction of the grain component led to a higher moisture content in the end product. The pressing process is necessary to obtain a moisture content of a clot $74 \pm 1 \%$. Physico-chemical properties of the end product are shown in Table 2.

The increase of mass fraction of spelt to $50 \%$ led to a deterioration of the organoleptic properties of the product, so adding spelt to the curd base in an amount of $37.5 \%$ of total mass was recommended.
The amino acid composition and content of basic food components of the developed product was determined. Biological and energy value and the degree to which the needs of proteins, fats and carbohydrates were met by consumption of $100 \mathrm{~g}$ of the product were calculated (Table 3-4).

The carbohydrate component of the product contains (g $100 \mathrm{~g}^{-1}$ of product): $2.09 \pm 0.3$ fiber; $1.96 \pm 0.29$ non-starch polysaccharides; $5.10 \pm 0.74$ starch.

\section{The choice of flavoring}

The developed product had a specific taste, due to its chemical composition. In order to make the taste of the product desirable for a wide range of consumers and expand the range, different flavorings were selected.

Figure 3 shows the comparative organoleptic evaluation of curd product samples with various fillers.

It was assumed that the maximum score for each of the characterized factors is 5 points. Best compatibility was observed when we added dried prune to the curd product in a quantity of $10 \%$ by weight of the product, and fruit puree with banana flavor in a quantity of $3 \%$.

Table 2. Physico-chemical properties of curd products with spelt

\begin{tabular}{crrrr}
\hline \multirow{2}{*}{ Indicator } & \multicolumn{4}{c}{ Mass fraction of spelt, \% } \\
\cline { 2 - 5 } & \multicolumn{1}{c}{0} & \multicolumn{1}{c}{25} & \multicolumn{1}{c}{37.5} \\
\hline Moisture content, $\%$ & $74.5 \pm 0.4$ & $78.3 \pm 0.4$ & $79.8 \pm 0.4$ & $80.9 \pm 0.5$ \\
Titratable acidity, ${ }^{\circ} \mathrm{T}$ & $138.0 \pm 4.0$ & $126.0 \pm 4.0$ & $118.0 \pm 4.0$ & $108.0 \pm 3.0$ \\
\hline
\end{tabular}

Table 3. The content of the nutrients in the end product, $\mathrm{g} 100 \mathrm{~g}^{-1}$ of product

\begin{tabular}{lccccc}
\hline \multirow{2}{*}{ Components } & Daily need & \multicolumn{2}{c}{ Curd product } & \multicolumn{2}{c}{ Skim curd } \\
\cline { 3 - 6 } & & table of contents & $\begin{array}{c}\text { percentage of the } \\
\text { daily requirement }\end{array}$ & daily need & $\begin{array}{c}\text { percentage of the } \\
\text { daily requirement }\end{array}$ \\
\hline Proteins & 60 & $7.6 \pm 0.9$ & 10.1 & 18.0 & 24.0 \\
Fats & 290 & 0.9 & 1.5 & 0.6 & 1.0 \\
Carbohydrates & 2000 & $7.6 \pm 1.4$ & 3.3 & 1.5 & 0.5 \\
Energy value, kilocalories & & 76.9 & 3.8 & 86.0 & 4.3 \\
\hline
\end{tabular}


Zabodalova, L. A., Belozerova, M. S., Evstigneeva, T. N. (2018). Manufacturing of curd products of increased biological value for the elderly from dried components. Acta Sci. Pol. Technol. Aliment., 17(2), 177-184. http://dx.doi.org/10.17306/J.AFS.2018.0545

Table 4. The biological value of the protein component of the curd product and skimmed curd

\begin{tabular}{|c|c|c|c|c|c|c|}
\hline \multirow[b]{2}{*}{ Amino-acid } & \multicolumn{4}{|c|}{ Amino acid content, g $100 \mathrm{~g}^{-1}$ of protein } & \multicolumn{2}{|c|}{ Amino-acid score, $\%$} \\
\hline & $\begin{array}{c}\text { protein } \\
\text { FAO WHO }\end{array}$ & $\begin{array}{l}\text { the ideal protein } \\
\text { for an elderly person }\end{array}$ & curd product & skimmed curd & curd product & skimmed curd \\
\hline Valine & 5.0 & 5.0 & 2.76 & 5.50 & 55.2 & 110.0 \\
\hline Isoleucine & 4.0 & 4.0 & 1.71 & 5.56 & 42.8 & 140.0 \\
\hline Leucine & 7.0 & 7.0 & 5.58 & 10.28 & 79.7 & 146.9 \\
\hline Lysine & 5.5 & 5.8 & 4.35 & 8.05 & 75.0 & 139.0 \\
\hline Metinin + cystine & 3.5 & 3.8 & 2.16 & 3.50 & 56.8 & 92.1 \\
\hline Phenylalanine + tyrosine & 6.0 & 6.0 & 4.71 & 10.33 & 78.5 & 172.2 \\
\hline Tryptophan & 1.0 & 0.8 & 0.42 & 1.00 & 52.5 & 125.0 \\
\hline Threonine & 4.0 & 4.0 & 1.97 & 4.44 & 49.3 & 111.0 \\
\hline \multicolumn{5}{|c|}{ Coefficient of rationality amino acid composition } & 0.67 & 0.69 \\
\hline \multicolumn{5}{|c|}{ Index comparable redundancy } & 0.19 & 0.16 \\
\hline \multicolumn{5}{|c|}{ Coefficient differences amino-acid score (CDAS) } & 18.5 & 37.4 \\
\hline \multicolumn{5}{|c|}{ Bioavailability (BA), \% (BA = $100-$ CDAS) } & 81.5 & 62.6 \\
\hline
\end{tabular}

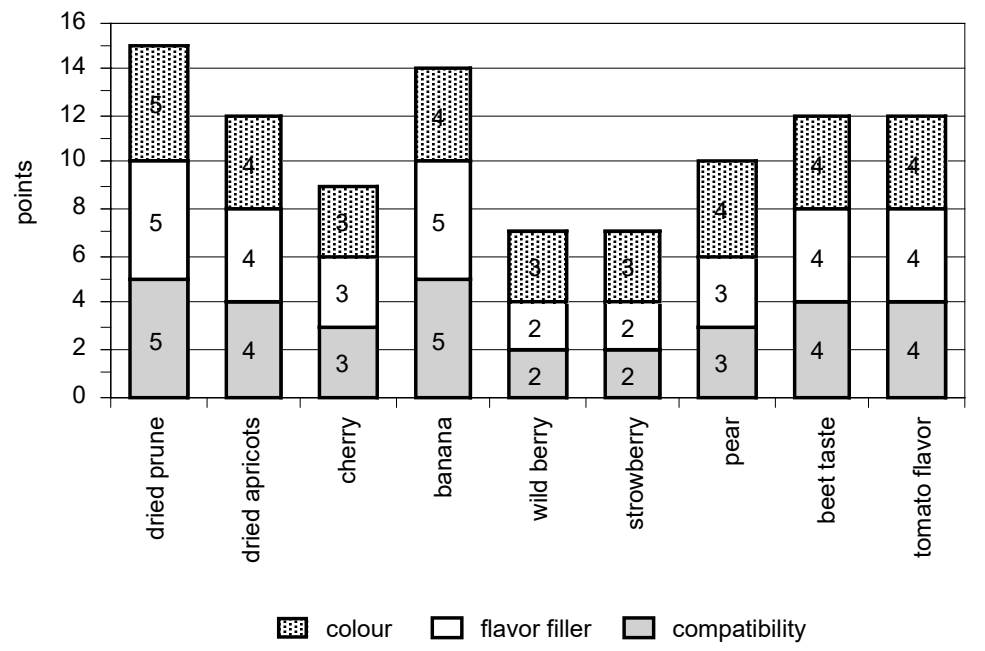

Fig. 3. Characterization of the samples of curd product with various fillers

\section{CONCLUSIONS}

The composition of low-fat curd product was substantiated on the basis of theoretical and experimental investigations. The product contained skimmed dried milk, isolated soy protein and spelt. The curd product had a higher biological value of protein. The curd product was designed for the nutritional needs of elderly people and can be recommended to other demographic groups as an additional source of animal 
Zabodalova, L. A., Belozerova, M. S., Evstigneeva, T. N. (2018). Manufacturing of curd products of increased biological value for the elderly from dried components. Acta Sci. Pol. Technol. Aliment., 17(2), 177-184. http://dx.doi.org/10.17306/J.AFS.2018.0545

and vegetable proteins. The developed curd product had a high biological value. The biological value of the protein component of the product was $81.5 \%$, and $62.6 \%$ for skimmed curd. The curd product contained larger amounts of carbohydrates, so the total amino acid content was lower than in the skimmed curd. The range of amino acids was larger, as evidenced by the coefficient of differences of the amino-acid score. This coefficient indicates the value of surplus amino acids, which are not used for the structural needs. The smaller the coefficient, the greater the number of amino acids used by the body for its structural needs, and consequently, the higher the biological value of the protein product.

\section{ACKNOWLEDGEMENTS}

The author, M. Belozerova, would like to thank her parents, Sergey Anatolyevich and Elena Ivanovna, and supervisor, Prof. Doctor of Technical Sciences Ludmila Alexandrovna Zabodalova.

\section{REFERENCES}

Akatsu, H., Nagafuchi, S., Kurihara, R., Okuda, K., Kanesaka, T., Ogawa, N., ..., Maruyama, M. (2016). Enhanced vaccination effect against influenza by prebiotics in elderly patients receiving enteral nutrition. Geriatr. Gerontol. Int., 16(2), 205-213. http://dx.doi.org/10.1111/ ggi. 12454

Andreenko, L. G., Antipova, T. A., Simonenko, S. V. (2007). Voprosy pitaniâ požilyh [Issues of nutrition older]. Moscow: Russian Academy of Agricultural Sciences [in Russian].

Bazenova, I. A. (2004). Issledovanie tehnologičeskih svojstv zerna polby (Triticum dicoccum Schrank.) i razrabotka kulinarno [Investigation of the technological properties of grain spelt (Triticum dicoccum Schrank.) and the development of culinary production with its use]. Abstract of the thesis for the degree of Candidate of Technical Sciences. Saint Petersburg [in Russian].

Cichero, J. A. Y. (2016). Adjustment of food textural properties for elderly patients. J. Text. Stud., 47(4), 277-283. http://dx.doi.org/10.1111/jtxs. 12200

Hezeker, G. (2000). Dannye o sostoânii zdorov'â dlâ vyrabotki rekomendacij po pitaniû [Data on health status for development of recommendations on nutrition]. Issues Nutr., 69(3), 8-13 [in Russian].
Kozlov, S. G. (2004). Proektirovanie strukturirovannyh produktov složnogo syr'evogo sostava [Design of structured products complicated raw composition]. Food Ind., 8, 74-75 [in Russian].

Kuznecov, V. V., Schiller, G. G. (2006). Ispol'zovanie suhih moločnyh komponentov $\mathrm{V}$ piŝevoj promyšlennosti. Spravočnik [Using dry dairy ingredients in the food industry. Reference book]. Saint-Petersburg: GIORD [in Russian].

Petrov, A. N., Grigorov, U. G., Kozlovskaia, S. G., Ganina, V. I. (2001). Gerodietičeskie produkty funkcional'nogo pitaniâ [Products for elderly people functional nutrition]. Moscow: Kolos Press [in Russian].

Prianischnikov, V. V., Miklaschevski, P., Ladd, H., Krasulia, O. N. (1999). Funkcional'nye dobavki napravlennogo dejstviâ dlâ piŝevoj promyšlennosti [Functional additives directed action for the food industry]. Food Proces. Ind., 1, 54-56 [in Russian].

Ruibal-Mendieta, N. L., Delacroix, D. L., Mignolet, E., Pycke, J.-M., Marques, C., Rozenberg, R., ..., Larondelle, Y. (2005). Spelt (Triticum aestivum ssp. spelta) as a source of breadmaking flours and bran naturally enriched in oleic acid and minerals but not phytic acid. J. Agric. Food Chem., 53(7), 2751-2759. http://dx.doi. org/10.1021/jf048506e

Serpen, A., Gokmen, V., Karagoz, A., Koksel, H. (2008). Phytochemical quantification and total antioxidant capacities of Emmer (Triticum dicoccon Schrank.) and Einkorn (Triticum monococcum L.) wheat landraces. J. Agric. Food Chem., 56(16), 7285-7292. http://dx.doi. org/10.1021/jf8010855

Shetinin, M. P., Mysina, O. N. (2002). Primenenie proroŝennyh zlakov $\mathrm{v}$ kombinirovannyh tvorožnyh izdeliâh [The use of germinated cereals in combined curd products]. Storage Proces. Agric. Raw Mater., 12, 40-41 [in Russian].

Tihomirova, N. A. (2001). Tehnologiâ produktov lečebnoprofilaktičeskogo pitaniâ. Učebnoe posobie [Technology of therapeutic and prophylactic nutrition. Study guide]. Moscow: MSUFB [in Russian].

Tutelian, V. A., Kniazev, V. A. (2000). Realizaciâ koncepcii gosudarstvennoj politiki zdorovogo pitaniâ naseleniâ Rossii: naučnoe obespečeni [Implementation of the concept of state politics of healthy nutrition of the population of Russia: scientific support]. Issues Nutr., 69(3), 4-7 [in Russian].

Yukov, V., Lihacheva, E. (2005). Sostav zerna volžskoj polby [The composition of Volzhskaya grain spelt]. Bread Prod., 7, 26-27 [in Russian]. 